\title{
Towards an Economic History of Customary Practice: Bread, Money, and the Economy of the Bazaar. Observations on Consumption and Cheating in the Late Medieval Foodstuffs Market
}

\section{Valentin Groebner (University of Basel)}

The relationship between money (usually the daily wage for qualified male workers, though this is not normally stated explicitly) and foodstuffs (usually grain) has long been the starting point and basis for assessment in attempts to establish the income and living conditions of broad sectors of the population in the late medieval towns. In the following article, this relationship will be examined in a large town at the end of the Middle Ages-Nuremberg in the years between 1470 and $1510 .{ }^{1}$ My use of the term 'relationship' rather than 'prices' or 'purchasing power' is deliberate. The intention is not to investigate long-term trends, changes in monetary values, and late medieval 'market baskets', but rather to provide a 'snapshot' of the conditions in which the foodstuffs required for daily life were purchased in a large town in the late Middle Ages, and thus of the real prices facing the inhabitants of Nurembergor at least the majority of them-at the end of the fifteenth century. I will attempt to show that the relationship between bread and money can be only imperfectly illustrated by the curve of bread prices. In reality, if we are honest, it is very difficult to link the changes in the price of grain in Nuremberg ${ }^{2}$ between 1470 and 1510 to the real living conditions of the town's poor. How can the history of prices be expressed in a way which also does justice to the position of the consumers?

1 This article was written in conjunction with a larger study of the economic practices of the lower classes in the towns of the late Middle Ages: V. Groebner, Ökonomie ohne Haus. Zum Wirtschaften armer Leute in Nürnberg am Ende des 15. Jahrhunderts (Göttingen 1993).

2 An excellent survey of rye prices in Nuremberg, and a corrective to incorrect and incomplete older figures, is provided by W. Bauernfeind, 'Brotgetreidepreise in Nürnberg 1427-1538', in Nürnberg und Bern. Zwei Reichsstädte und ihre Landgebiete (Erlangen, 1990), pp. 169-225 (=Erlanger Forschungen 46). 
Wilhelm Abel's classic comparison of artisan wages and grain prices in the fifteenth century, seen as evidence of a 'golden age of wage labour', has been increasingly criticized and his findings of a 'comfortable life' and cheap basic foodstuffs in the towns of the late Middle Ages subjected to thorough revision. ${ }^{3}$ However, the customary method of investigating living standards and developments in the purchasing power of income from wage labour has remained: the comparison of the daily wage of an artisan (male, according to the unspoken assumption that this is 'representative') with its equivalent in grain. According to a recent analysis, for example, a journeyman in the Nuremberg building trade would have been able to buy $13.7 \mathrm{~kg}$ of rye with his daily wage in $1470,14.2 \mathrm{~kg}$ in 1475 , and $9.5 \mathrm{~kg}$ in $1495 .{ }^{4}$

Could he really do so? Even though the author of this calculation draws attention to 'possible elements of great uncertainty', his figures miss the point in several respects. Broad annual averages tend to obscure the short-term fluctuations of 'rye purchasing power' and provide a more constant picture than was in fact the case. More important, however, is the fact that a Nuremberg building worker did not obtain unprocessed rye for his meals, but purchased it in the form of bread. At least in the minds of the people, bread was the main source of nutrition; at times of price increases, the attention of the authorities was also directed chiefly towards bread. Recent researchers have calculated how greatly the price of bread in late medieval towns was inflated by sales margins, losses of mills, millers' and bakers' profits, and municipal consumer taxes. Depending on the type (cheap dark or more expensive white bread), bread was between 40 and 80 per cent more expensive than the supposed measure of purchasing power, rye grain. ${ }^{5}$ Moreover, the history of prices has revealed a strange phenomenon, which has been known for some time: grain prices in the late Middle Ages either did not respond at all to depreciations in the value of money, however drastic, or they did so only belatedly and to a limited extent. In late medieval Nuremberg, grain was traded almost exclusively in silver money, in Pfennige; ${ }^{6}$ the value of the

${ }^{3}$ See e.g. U. Dirlmeier, Untersuchungen zu Einkommensverhältnissen und Lebenshaltungskosten in oberdeutschen Städten des Spätmittelalters (Heidelberg, 1978); and recently E. Schubert, Einführung in die Grundprobleme der deutschen Geschichte des Spätmittelalters (Darmstadt, 1992).

4 P. Fleischmann, Das Bauhandwerk in Nürnberg vom 14. bis zum 18. Jahrhundert (Nuremberg, 1985), pp. $177 \mathrm{f}$.

5 U. Dirlmeier, 'Zum Problem von Versorgung und Verbrauch privater Haushalte im Spätmittelalter', in A. Haverkamp (ed.), Haus und Familie in der spätmittelalterlichen Stadt (Cologne/ Vienna, 1984), pp. 257-88, here p. 281.

6 The municipal guide prices for rye were always in silver money; also, in the buying and selling of grain in the municipal court books, the price for the dry measure of rye was always given in Pfund/Pfennige. The only (and probably significant) exceptions were the crisis maximum prices in the inflationary crises of $1482-3$ and $1502-3$, which were noted by the contemporary chroniclers in Gulden. See e.g. K. Hegel (ed.), Die Chroniken der deutschen Städten vom 14. bis ins 16. Jahrhunderte (hereafter cited as Chroniken), vol, 11 (Leipzig, 1872), pp. 368, $634 \mathrm{f}$. 
Nuremberg Pfennige as against the more stable Gulden fell continuously in the second half of the fifteenth century. ${ }^{7}$ Why did the price of the dry measure of grain not rise when the money for which it was sold contained less and less silver? There is an obvious explanation which has already been advanced by earlier economic historians and has been made even more plausible by research in the last few years: it was the shortage of money which kept prices down. In his investigation of journeymen and and wage labourers in the Upper Rhine, Knut Schulz observed that in the towns of the late fifteenth century, the increase in the supply of money lagged behind demand. Debased coins thus failed to unleash price increases or inflationary tendencies, particularly as the population accepted the devalued money (while in the relatively coin-rich sixteenth century comparatively small debasements of the coinage triggered an explosive rise in prices). ${ }^{8}$ This appears strange to us, since for us the price of an item is a self-evident and more or less universal indicator of its scarcity or its value. In late medieval Nuremberg, however, grain and silver money were, in a way, equal; both were goods available only in limited amounts and were occasionally scarce, and the price of grain simply gives their actual exchange relationship.

If we wish to assess the purchasing power of the daily wage of late medieval wage labourers, we cannot use grain in wholesale trade quantities (and at wholesale prices) as our indicator. Even in normal years there were considerable seasonal fluctuations in grain prices. The recipients of small incomes were not in a position to lay in significant stores of bread grain in the months following the harvest, when the price was usually much lower. Throughout the year they remained dependent on the movements in the market price for more expensive bread. ${ }^{9}$ Because they were purchasing for short periods, they were forced to follow every fluctuation in the price of grain during the year between harvests; for that reason, they paid considerably more on average for their bread than their wealthier fellow citizens, who were able to lay in a year's supply of cheap September grain and have it made into bread by wagebakers as required. ${ }^{10}$ There was thus a clear social differentiation in the grain price. The various different price levels which existed cannot be equated one with another or blended together: first, the wholesale prices with their monthly fluctuations, the rate at which the Heilig-Geist-Spital, for example, would buy

7 H. Eichhorn, Der Strukturwandel im Geldumlauf Frankens zwischen 1437 und 1610 (Wiesbaden, 1973), p. 225; see also E. Scholler, Das Münzwesen der Reichsstadt Nürnberg im 16. Jahrhundert (PhD Erlangen, 1912).

${ }^{8} \mathrm{~K}$. Schulz, Handwerksgesellen und Lohnarbeiter. Untersuchungen zur oberrheinischen und oberdeutschen Stadtgeschichte des 14. bis 17. Jahrhunderts (Sigmaringen, 1985), p. 324.

9 See Chroniken, ii. 299 (official register of corn stocks in the city 1449); Dirlmeier, Untersuchungen, p. 51 ; id., 'Versorgung', pp. 267 f. See also H. Hofmann, Die Getreidehandelspolitik der Reichsstadt Nürnberg, insbesondere vom 13. bis zum 16. Jahrhundert (Nuremberg, 1912), p. 52.

io On seasonal prices in Nuremberg, see Bauernfeind, 'Brotgetreidepreise', pp. 207 f.; also C.-M. de la Roncière, Prix et salaires à Florence au XIVe siècle (Rome, 1982), pp. $71 \mathrm{f}$. 
its grain and which provided the official guide prices of the wholesale trade, the raittung, in the council books and records from 1489; second, the speculative peak prices which emerged in the years of price increases and which the chroniclers noted with striking frequency in gold; and third, the price of bread, burdened as it was with various extra costs and profit margins (and from 1504 with the municipal consumer tax on grain). Clearly it is only the last of these price levels-that which relates to bread-which can be compared with the income earned in the daily wage of artisans.

In November 1442 the Nuremberg council ordered that light wheat-mixed bread and rye bread, which was on sale in the town for one Haller (the smallest silver coin), should be bought secretly from twenty-eight of the town's bakers and its weight investigated. The result was alarming: the councillors entrusted with the task reported that 'die pecken die hallerwert prot vast clein und ungeleich ein vil grösser dann der andere packen' ('the bakers are baking the one-haller bread too small and some are baking it much bigger than others'). In fact, the weight of the bread varied significantly. From the baker Jung Ofner, for example, two Haller would purchase two loaves of white bread weighing $345.14 \mathrm{~g}$, but from the baker Vogel the loaves weighed only $263.5 \mathrm{~g}$. The variations in the cheaper rye bread were even greater: for two Haller the baker Wolfflein sold rye bread weighing $627.2 \mathrm{~g}$, but for the same price the bread sold by the baker Vogel weighed only $523.3 \mathrm{~g}-14$ per cent less. The amount of bread received for one Haller obviously depended on the baker from whom it was bought. ${ }^{11}$

These inquiries formed part of the preliminary work of the council for a revision of the Brotordnung following the price-rise crises of 1432-4 and 14379. The new regulation came into force in October 1443: its core was a table of bread weight, the raitungspene, which fixed the weight of a loaf of bread worth one Pfennig depending on the current price of the Sümer (the Nuremberg dry measure, around 318 litres) of rye. In late medieval towns this was normal practice. The price of the bread remained the same, at 1 Pfennig $(d)$, according to the Nuremberg table. If the Sümer price rose, the bread became not dearer, but smaller and lighter; if the price fell, the loaves were made bigger and heavier. The flexible element, which expressed the relationship between commodity and money, was not the price of the bread but its weight. Some other foodstuffs which were subject to similar seasonal fluctuations in price were sold in the same way: at a fixed price but in varying quantity. It was a practice which went hand in hand with the lack of divisional coins and the scarce supply of money. ${ }^{12}$

In order to discover the purchasing power of daily wages in terms of the actual food they could buy, it is necessary to convert the Nuremberg rye prices, with the aid of the municipal table, into the corresponding weight of

1 Stadtarchiv Nürnberg, A22, Amb. 31, f, 51r-53r.

12 Eggs are frequently cited as an example. See Schulz, Handwerksgesellen, p. 423; similarly 
bread which could be purchased for one Pfennig..$^{13}$ An account of the bread weight enables us to obtain a more accurate idea of actual conditions because it turns on the relationship between the two scarce commodities of bread and small coin. Such a result comes much closer to the experiences and consumption practices of the inhabitants of Nuremberg than the usual index calculations. How many grams of bread was the Pfennig worth?

\section{II}

Such an account of the weight of bread in Nuremberg between 1470 and 1510 certainly helps to illuminate the clear short-term changes in the breadpurchasing power of the local silver money, yet it gives no more than a partial description of actual conditions. There are two reasons for this.

First, it is restricted only to the cheapest kind of bread, the relatively coarse rye bread, which was baked hard and dark. Perhaps in order to make it keep longer, it was apparently supposed to be baked as dry and hard as possible. The bread baked in 1449 under the auspices of the municipal authorities was particularly praised for its firmness ${ }^{14}$ and in his account of the municipal baking of 1501-3, Anton Tucher declared that the bread was coarser than was customary and was also kept for eight days before being distributed-'das hat auch wol ersprossen'. ${ }^{15}$ Other contemporary voices were less happy with the hard, coarse rye bread. The Nuremberg artisan poet Hans Rosenplüt told the mocking tale of a mean and lazy baker who fed his journeymen badly with 'hert keß und grob prot'; ${ }^{16}$ in $1490 \mathrm{Kunz}$ Has, in his poem in praise of Nuremberg, reserved particular praise for its tight controls on the bakers: ${ }^{17}$ 'wie sy die laib söllen machen/ein rechte grösse und nit ze grob. Sollich regiment ich billich lob.'

According to Has, the bread should not be baked too coarsely-in the case of bread, as with other foodstuffs, there was a clear and fairly drastic social differentiation. The lighter and finer the bread, the better and healthier it was regarded as being. The Nuremberg Stadtarzt Dr Johannes Lochner, who in 1480 collected medical advice for his son on ways to keep healthy while travelling, regarded dark rye bread as completely indigestible and demanded that bread should be made from pure wheat flour. It should also be white in colour and sweet to taste and should be a day old at most; the coarse crusts should be removed before it was eaten. ${ }^{18}$ As well as being a particular taste,

Staatsarchiv Nürnberg, Rep. 60 b, Ratsbücher (hereafter abbreviated to RB), 2, f. 279r (1479).

${ }_{13}$ See, in detail, Groebner, Ökonomie p. 82.

14 Stadtarchiv Nürnberg, A22, Amb. 31, f. 67r.

is Chroniken ii. 305 (1449) and xi. 635 (1503).

${ }_{16}$ Printed in K. Euling, Das Priamel bis Hans Rosenplüt (Breslau, 1905), pp. 557 f.

17 K. A. Barack (ed.), Ein Lobgedicht auf Nürnberg aus dem Jahre 1490 von dem MeisterSänger Kuntz Has (Nuremberg, 1858), p. 25.

${ }_{18}$ H. J. Vermeer (ed.), 'Johannes Lochners "Reiseconsilia"', in Sudhoff's Archiv. Zeitschrift für Wissenschaftsgeschichte 56 (1972), 145-96, here pp. $159 \mathrm{f}$. 
this was also a rather expensive one, since in Nuremberg this kind of white bread, light and finely sieved, known as semel and usually baked with twothirds wheat and one-third spelt with the husks removed, was comparatively dear. We have already seen that in 1442 it was possible to buy only about half as much white bread as rye bread for one Pfennig ( $=2$ Haller) ${ }^{19}$ At the end of the fifteenth century, however, white bread appears repeatedly in books of accounts, food regulations, and bills for food, showing that it had become part of the regular food of Nuremberg wage labourers. The weight table of 1443 relates to rye bread alone, a sort of smallest common denominator of the daily menu.

The second restriction on the validity of the bread-weight curve rests on a more fundamental problem - the gulf between late medieval norms and actual conditions. The Nuremberg Brotordnung of 1443 laid down that the bakers had to manufacture their bread according to the prescribed weight; only loaves baked to a weight equivalent to one, two, four, or six Pfennige were permitted. ${ }^{20}$ All other bread weights were illegal, and for bakers who fell below the bread weights the police regulations and the rules controlling bakers in the Ratsverlässen established penalties which included fines, imprisonment, and the temporary closure of businesses. In their panegyrics to Nuremberg in 1490 , Konrad Celtis and Kunz Has both stress the tight municipal controls on the bakers in the form of an extensive system to control the weight and quality of the bread sold within the town. ${ }^{21}$ Alongside a committee of specially swornin master bakers (the only permitted institution of craft self-administration: guilds were forbidden in Nuremberg) there were a number of special municipal officials, chief among them the bailiff (Pfänder), who was responsible for the observation of the craft and police regulations. Subordinate to him were the market guards (Marktmeister) and a number of lower officials including the controllers in plain clothes, 'des pfenters heimliche knechte'. Judging by the wording of their ordinances, the Nuremberg authorities exerted strict and extensive craft supervision. In view of the 'strict controls on price and quality', earlier researchers have considered that the council exercised 'patriarchal care'; the municipal controls on commodities were believed to show 'all the marks of welfare relief and brought good results'. From their examination of the municipal apparatus of control and ordinance-making, other researchers have even concluded that 'in view of the strict quality controls and fixed prices

19 See also Dirlmeier, 'Versorgung', p. 283.

20) Stadtarchiv Nürnberg, A22, Amb. 31, f. 54v. White bread was also sold in loaves at one Haller.

${ }_{21}$ See Hofmann, Getreidehandelspolitik, p. 21; A. Jegel, 'Die Ernährungsfürsorge des AltNürnberger Rates', Mitteilungen des Vereins für die Geschichle Nürnbergs (hereafter abbreviated to MVGN 37 (1940), 37-199, here p. 57; on Celtis and Has see A. Werminghoff, Konrad Celtis und sein Buch über Nürnberg (Freiburg im Breisgau, 1921), pp. 167-71; also Barack, Has, pp. $25 \mathrm{f}$. 
for foodstuffs imposed by the council, life in Nuremberg at the end of the Middle Ages was cheap'. ${ }^{22}$

The council records in the late fifteenth century actually dealt strikingly often with the issues of bread weight and controls on bakers. On numerous occasions the council felt compelled to exhort the bakers to bake smaller loaves for one Pfennig as well as the larger loaves. In 1457 it was stipulated that the bakers should continue to make small loaves so that the poor could buy food for themselves at market; similar ordinances were issued on several occasions at the beginning of the $1480 \mathrm{~s} .{ }^{23}$ Even more frequent were reminders to the bailiff to work with the sworn master bakers in order to ensure the observation of the Brotordnung and of bread weights. In 1477, 1478, 1480, and 1491 the bakers as a body were reprimanded for making their bread too small and inadequate. Then, in 1492 , the council decided to remind them 'ernstlich' to bake their breads according to the prescribed weight: they were warned not to give the council cause to examine the weight of the bread they sold-' 'to get out the scales again', as the protocol put it. ${ }^{24}$ Apparently normal controls did not involve checking the weight, showing that the authorities took an elastic approach to their own rules. In 1481 the bakers were assured that baking white bread up to $2 \mathrm{lot}$, and rye bread up to $3 \mathrm{lot}$, below the prescribed weight would in future go unpunished. Deviations from the prescribed weight which the council regarded as 'ungeverlich' were as high as 20 per cent for white bread and 16 per cent for rye bread; the bakers could thus bake their bread either one-fifth or one-sixth lighter than the official weight without punishment! $!^{25}$ In May 1482, when the price for the Sümer of rye had risen considerably in a period of price increases, the council relaxed the regulations still further. Similarly, during the price rises of 1491-2 the bailiff was ordered to be lenient in controlling the bread weight. ${ }^{26} \mathrm{~A}$ certainnot inconsiderable-failure to meet the bread weight was tolerated by the authorities.

However, the council did not only issue warnings and exhortations. In 1476 the bakers Baireutter, Schnittner, Krantz, and Koburger were sentenced to

22 See Hofmann, Getreidehandelspolitik, pp. 10-12, 21, 79; Jegel, 'Ernährungsfürsorge', pp. 83-7 and 11; quoted in $\mathrm{H}$. Weiss, Lebenshaltung und Vermögensbildung des 'mittleren' Bürgertums. Studien zur Sozial- und Wirtschaftsgeschichte der Reichsstadt Nürnberg zwischen 1400 und 1600 (Munich, 1981), p. 81.

${ }^{23}$ RB 1 b, f. 312 r (1457). At Easter 1482 the bakers were forbidden to sell white bread for 1 Pfennig and were told to continue offering the light bread at $1 \mathrm{Haller}$; at the beginning of May 1482 they were given permission to do so, but were told that they must always offer hallersemel for the poor at the same time: StaatsAN Rep. 60a, Ratsverlässe 143, f. 1r and 19r (hereafter abbreviated to RV). Similarly RB 3, f. $183 \mathrm{v}$ and RB 5, f.299r-an indication that the poor also ate white bread.

${ }_{24}$ RB 2, f. 178r (1477); RB 97, f. 25v (1478); RV 118, f. 7v (1480); RV 251, f. 12r (1490); RB 5, f. $229 \mathrm{v}(1492)$.

${ }_{25}$ RV 136, f. 9r (1481). See Stadt AN A 22, Amb. 31, f. 51v; Bauernfeind, Brotgetreidepreise, p. 213.

${ }_{26}$ RB 3, f. 183v (1482); Jegel, 'Ernährungsfürsorge', p. 83 (1492-3). 
fourteen days and nights in prison and to temporary closure of their businesses for baking their loaves much too small. In 1481 the bakers Hans Baireutter and Class Furmann were punished with four days' imprisonment in the tower and temporary closure for the same reason. ${ }^{27}$ In July of the same year the bakers were forbidden to pay off in money the terms of imprisonment imposed on them; they were prevented from letting other bakers sell bread in their shops during their arrest and the temporary closure of their business; and they were not allowed to pay a fine in place of the temporary closures. Apparently the decree failed to have the desired effect, since in November 1481 it was again announced that bakers who violated the bread regulations were to be sent to prison as well as having their businesses temporarily closed; these punishments would have to be served and could not be converted into fines. ${ }^{28}$ However, an entry in the Ratsverlässe of 1490 reveals rather different treatment of Contz Koburger, a wealthy master baker and member of the Grösserer Rat. According to the protocol, he was to be punished according to the law for baking his loaves too small, but his term of imprisonment was to be 'forgotten'. Another instance of lenient applications of the laws can be found on the next page of the same protocol, with more bakers having their terms of imprisonment in the tower converted to house arrest. In July 1492 the council let Contz Koburger off altogether after another violation of the Brotordnung..$^{29}$ However, two years later the same council responded with irritation to an application from the sworn masters of the bakers' trade, requesting mercy for a colleague who had committed an offence. According to the protocol they were to be given a strefflich red because they had asked for a remission of punishment, which was against municipal laws. ${ }^{30}$ Only the council had the right to grant remission of punishment or pardons. Such remissions were not rare but in most cases they were made in secret-'in geheym'. They could, therefore, not be demanded openly. This, it would seem, was the faux pas for which the master bakers were being reprimanded. ${ }^{31}$

The Ratsverlässe in the council protocols and council books were not concerned solely with particular or major violations of the regulations, but also attempted to push through new rules when conditions changed. Smaller or 'normal' infringements of the bread regulations, on the other hand, were not the concern of the council but of the officials appointed for the purpose, and it is in their records that details can be found. The accounts of the bailiff,

27 RB 2, f. 66v (1476); RB 3, f. 136v (1481).

${ }^{28}$ RB 3, f. 99r and 144r. Terms of imprisonment could otherwise usually be converted into fines according to a fixed tariff. On the issue of new regulations in October 1487, see RB 4, f. 273.

${ }^{29} \mathrm{RV} 256$, ff. $14 \mathrm{r}$ and $14 \mathrm{v}$ (1490); RB 5, f. 225r (1492).

30) RB 6, f. $72 \mathrm{v}$.

31 In other cases there was pro forma payment of a fine: for an unnamed offence in 1492 Kraws Schmid was sentenced to pay a fine 'nach lawt des gesetzes' according to the council protocol: 'und er so das überantwurt, im das widerzugeben, biß an eynen gulden,' RB 5, f. 226r; similarly RV 237, f. 12v (1489). Not all the fines imposed, therefore, were actually paid. 
the head of the municipal executive, can be found at irregular intervals from 1477 onwards in the inventory of the Stadtrechnungsbelege of the Staatsarchiv Nürnberg. The bailiff collected fines for breaches of the peace, for exceeding maximum prices, and for violation of the laws on the market and the coinage. His accounts listed the amount of the fine, in most (but not all) cases the name of the offender, rather less often his trade and the nature of his offence. The register of fines thus has a number of important gaps: there are long periods for which no records exist; the offence is cited in only about one-third of the entries; and only in about half of the cases did the bailiff note the occupation of the culprit. ${ }^{32}$ Nevertheless, these accounts provide an informative sample by which to gauge the frequency of violations. On 24 October 1482, for example, the bailiff entered no fewer than 3,000 $d$ in fines from bakers for baking their loaves too small. Of the thirteen surviving bailiff's slips dating from the year 1483, eight cite fines for that same offence; of the eleven surviving slips from 1484 , no fewer than nine refer to fines on bakers. In November 1487 the bailiff collected $400 d$ in fines for making their loaves too small from each of the bakers 'Ulrich peck bey sant Jacob', Kornschreiber of the Heilig-Geist-Spital, and thirteen others. ${ }^{33}$

If something approaching an overall picture emerges from the Ratsverlässen and the accounts of fines, it is marked by the constant presence of cheating in business practices and of failure to keep to the required bread weights. ${ }^{34}$ There is no doubt that bread baked below the required weight was part of the reality of life for buyers in Nuremberg at the end of the fifteenth century. In other words, a certain degree of cheating by the bakers was normal. Though the values of the bread-weight curve offer some clues about the fluctuations in the bread-purchasing power of the Nuremberg Pfennig, they cannot therefore be regarded as hard data.

It was not only the bakers who cheated. In the literature of the fifteenth century there are frequent complaints about unspeakable practices in the foodstuffs business in general. Popular Nuremberg artisan poetry offers a vivid picture of everyday cheating and over-charging. In a work dating from the middle of the century, Hans Rosenplüt claims that 'die pirprew eilf jar pirprewn, geben/zehen jar rus, hopf und wasser darneben' and in one popular and ironic epigrammatic poem lists a number of comic and improbable figures: the innkeeper who never swindles his guest, the merchant who always tells

${ }^{32}$ In some years the accounts are plentiful, in others they are lacking altogether. The first (far from complete) is dated 1477; the last which is relevant to our period comes from January 1500 . During the 24 years in between, bailiff's slips have survived from 14 accounting years: StaatsAN Rep. 54a I, 63, 111, 157, 187, 200, 260, 279, 368, 381, 471, 500, 657 .

${ }^{33}$ Ibid: I 111 (1482), I 157 (1483), I 187 (1484) and I 279 (1487).

34 A number of bakers punished for making their loaves too small later appear as members of the supervisory committee of geschworen maister, e.g. Hans Baireutter and Jorg Hertl: Ämterbücher Staatsarchiv Nürnberg Rep. 62, Nr. 12, f. 11 r (1489) and Nr. 13, f. 13r (1490). 
the truth, and the shopkeeper who never cheats his customers. ${ }^{35}$ In a panegyric to Nuremberg printed in 1490, Kunz Has gives details of the tight municipal controls on goods and the strict punishments for swindlers; he has special praise for the council's close supervision of the butchers, which prevented people from being cheated with inferior cuts or meat from mangy animals. Sebastian Brant also credited the butchers with special skills at cheating: one section of his Narrenschiff is called 'Von falsch und beschiß' and describes in malicious detail how the butchers in the market manipulate their weights and measures:

und frogen eyns/wie vil man heysch

den taumen wigt man zu demm fleysch. ${ }^{36}$

Weights and measures were also manipulated in the sale of other foodstuffs. Every year on Margarete ( 13 July), all the pots and measures used by the innkeepers and dealers in foodstuffs were supposed to be examined by the council. This examination was apparently insufficient, and the council employed secret controllers and informers in addition to the bailiff. ${ }^{37}$ In fact, each of the surviving punishment registers of the city accounts contains details of fines imposed for the manipulation of weights. One list of March 1476 gives the names of forty-three people who were punished for using false weights and measures-with fines of $8,420 d$ overall ${ }^{38}$ According to the city accounts, in 1482 the butcher Ulein Neuß alone paid no less than $600 d$ in fines for cheating with his weights; four of his fellow-butchers had to pay fines of between 250 and $600 d$ for false weighing of meat. In May of the same year Neuß appears in the bailiff's accounts with an additional fine for fürkaufs of meat, while his wife was fined another $180 d$ because of scales which had been the subject of complaint. ${ }^{39}$

Punishments for exceeding the maximum prices were mentioned even more frequently, especially for meat. Of the twenty-three bailiff's slips surviving from 1482 and 1483, fourteen list fines because of 'flaisch höher gebens'; in total during this period, sixty people-not including the bakers-were forced to pay fines for exceeding the maximum prices, for fürkauf of foodstuffs, or for cheating with the weights. The bailiff's slips for the 1490s, fewer of which have survived, do not show any significant reduction in these offences. The latest from the period under investigation, the bailiff's accounts slip for January 1500 , contains no fewer than eight punishments for butchers; for selling sausages too dear, for keeping back goods, and for exceeding the maximum prices. This last offence alone was punished on five occasions, once

${ }^{35}$ K. Euling (ed.), Hundert noch ungedruckte Priameln des 15. Jahrhunderts (Paderborn/ Münster 1887), p. 85; Euling, 'Das Priamel', pp. 547 f.

${ }^{36}$ Barack, Has, p. 24; S. Brant, Das Narrenschiff. Nachdruck nach der Erstausgabe von 1494 (Tübingen, 1968), p. 270.

37 Staatsarchiv Nürnberg, Rep. 52b, Nr. 231, f. 332r-66r; Jegel, 'Ernährungsfürsorge', p. 110.

38 Staatsarchiv Nürnberg, Rep. 54a, I 13.

${ }^{39}$ Ibid., Rep. 54, Nr. 18: f. 18r, f. 12r; Rep. 54a, I 111. 
with a fine of $300 d$ and four times with a fine of $600 d^{40}$ All this must be assessed against a background in which the offence and the offenders were named in only a small number of cases; the number of fines actually imposed for these offences was probably much higher. As in the case of the bakers, the accounts of fines provide details of no more than a section or sample of the offences. Nevertheless, certain butchers are cited in them so frequently that we can assume that the punishment registers reflect general and everyday business practices. ${ }^{41}$

\section{III}

Late medieval Nuremberg, with its cheating bakers and butchers, was not an isolated case. Long lists of punishments for exceeding the maximum prices and for inaccurate weights and measures appear in many of the surviving court sources of the late Middle Ages. This fact has led Gerhard Jaritz to call for 'greater evaluation and critical analysis' of such sources and to produce his own investigation of craftsmen's cheating in the late medieval period, ${ }^{42}$ though without opening up any new methodological approach to the problem. Is the only solution open to us to agree with the pithy but helpless comment of the Strasbourg shopkeepers' regulation of 1471 to the effect that there was 'vil beschisses' being done? ? $^{43}$

As a first step it is essential to examine conditions in the Nuremberg markets more closely. The fluctuations in the price of grain and in bread weight have already been mentioned, but the price of meat was subject to much less dramatic variation. In the decades between 1470 and 1510 , according to the recommended price, buyers paid between 3 and $5 d$ per pound for ox meat (of good quality $)^{44}$-these were stable conditions by comparison with those of bread, wine, or fat. As in the case of bread, however, these lists of maximum prices fixed by the authorities do not tell the whole story. Not only the recommended prices but also other regulations of the Nuremberg butchers' regulations (Fleischhackerordnung) were, it appears, continually violated. Specific practices such as price-raising agreements, the granting of preferential treatment to rich masters in the annual drawing of lots for the butchers' stalls, and the sale of diseased meat, were the order of the day. Can this be dismissed

40) Ibid., I 657.

${ }^{41}$ The butcher Ott Kraws, for example, paid a fine of $250 \mathrm{~d}$ for exceeding the maximum price in August 1478, $600 d$ in Aug. 1482, and $600 d$ on two occasions in 1483; in Feb. 1484 his wife was fined $600 d$ for cheating her customers with the weighing. Staatsarchiv Nürnberg, Rep. 54, Nr. 18, f. 18r; Rep. 54a, I 111, 157, and 187. Similar lists can also be drawn up for the butchers Hermann Sixt, Fricz Kugler, Hans and Erhard Schaller, and Cuntz Kraws.

${ }^{42}$ G. Jaritz, 'Die spätmittelalterliche Stadt in der Sachkulturforschung', in G. Wiegelmann (ed.), Geschichte der Alltagskultur (Munich, 1980), pp. 53-68, here p. 62. On cheating in the crafts, see also id., 'Handwerkliche Produktion und Qualität im Spätmittelalter', in Handwerk und Sachkultur im Spätmittelalter (Vienna, 1988), pp. 33-50.

${ }^{43}$ Quoted from Jaritz, 'Produktion', p. 34.

44 C. L. Sachs, 'Metzgergewerbe und Fleischversorgung bis zum Ende des 30 jährigen Kriegs', MVGN 24 (1922), 1-260, here p. 252. 
as no more than either an 'unscrupulous search for business' or the criminal energy of certain individuals in the late Middle Ages? ${ }^{45}$

In his Spruch vom eelichen Stand, written in 1500, the Nuremberg Meistersinger Kunz Has referred to those who ridiculed and cheated the devout poor ('und künnen felschen alle war/auch mit falschem gewicht und wag/secht, Got sendet uns vil plag').$^{46}$ As Has indicated, most of the forms of cheating recorded in the punishment register were clearly directed 'below'that is, against consumers who purchased small quantities on the market. This was particularly true of the widespread cheating with scales, and with the practice of holding meat back for bulk buyers. In a Ratsverlass of June 1481, the market guard was empowered to bring this reserved meat out of the butchers' chests and sell it on his own initiative. ${ }^{47}$ On several occasions there was also a ban on Zuwaage, meaning the practice of selling cheap meat only to those who bought the same amount of a more expensive cut as well. The council finally approved this practice in a Verlass of 1498 , but on condition that customers who bought less than two pounds of cheap meat were not to be forced to buy more goods. This was apparently an attempt to protect poor consumers. ${ }^{48}$ Accordingly, the bailiff collected fines not only for the keeping back of meat (as in 1482 from Hermann Sixt and in 1484 from Ulrich Kawrhain and several of his colleagues), but also for the coercion of customers into buying. ${ }^{49}$

The bailiff's accounts indicate, in particular, one further lucrative practice in the Nuremberg retail trade in foodstuffs. From the beginning of the 1480s, fines appear with increasing frequency for 'verpoten münz halb'-that is, for accepting or possessing silver money from outside, the circulation of which was forbidden in the city. On 17 December 1482, for example, he listed the names of twenty-five butchers all of whom had to pay a fine of $120 d$ for having forbidden 'foreign' money. In March 1487 he noted that he had collected $120 \mathrm{~d}$ 'münz halb' from the baker Ulrich; in October 1490 the foodstuffs dealer Heintz Haynshaymer was forced to pay $120 d$ for forbidden coins, and in November 1492 the baker Jörg Herttel was similarly fined. On the occasions when the bailiff's accounts give the trades of those who were fined for accepting and possessing foreign coins (unfortunately only about half), they were almost all in the foodstuffs trade. The vast majority were butchers, bakers, and other retailers of foodstuffs ${ }^{50}$ According to contemporary complaints it was precisely these pfenwerthändler, selling their goods for very small amounts of money-butchers, bakers, innkeepers, and shopkeepers - who collected the

45 Ibid. 16-18 and 101-6.

${ }^{46}$ Printed in E. Matthias, 'Der Nürnberger Meistersänger Kunz Has', MVGN 7 (1888), 169

236, here p. 201.

47 Sachs, 'Metzgergewerbe', pp. 30, 68.

48 Ibid. 209; see also Staatsarchiv Nürnberg, Rep. 52b, Nr. 231, f. 181r.

49 Ibid. Rep. 54a, I 111 (1482); I 187 (1484).

so Ibid.: I 111 (1482), I 381 (1490), I 471 (1492). 
most unreliable money. The Verlässe of the Nuremberg authorities are clear on this point: on 5 May 1492 the bailiff was ordered to warn against bad foreign coins and to control the bakers and shopkeepers because of their use of Pfennige from outside; in October of the same year the shopkeepers, butchers, and brewers were warned by the council not to accept forbidden silver money, or else risk severe punishment ${ }^{51}$ In a poem written in 1490 and printed in 1500, the Nuremberg Meistersinger Kunz Has complained that all the shopkeepers had become coiners. He accused them of various techniques of manipulating the coinage-of liquating, cutting, and melting down the good coins and, especially, of fraudulently exchanging the bad. ${ }^{52}$

Is there a connection between the frequent punishment of the foodstuffs trade for exceeding the maximum prices and the overwhelming predominance of its members among those punished for münz halb and the circulation of invalid or foreign coins? Apparently it was common practice to demand higher prices for payment in invalid or foreign coins-a highly profitable business if the butcher could return this forbidden money to circulation at a better rate. These forms of exchange were by no means unusual. ${ }^{53}$ In February 1482, the butchers Haintz Kraws and Steffan Slawrspach were each fined $300 d$ for requiring their customers to pay in the desirable gold currency of Gulden; these, unlike the 'black' municipal Pfennige, were not subject to a continuous fall in value or constantly mixed with suspect foreign money of doubtful value. ${ }^{54}$

In dealing with all these offences, punishments in Nuremberg contained no notion of recidivism. Despite infringements following one another in quick succession, the punishments remained unchanged as fixed in the craft regulations (Handwerksordnungen). But what was the aim of these punishments? The Nuremberg craft regulations were very strict for political reasons, in order to prevent any kind of artisan self-organization and zünfttisch wesen. For that reason, the crafts were not themselves permitted to administer the laws affecting them. The regulations of the Nuremberg butchers, for example, were anxiously guarded by the council: they were used mainly for the annual swearing-in of the masters and were otherwise accessible only to the municipal officials. Even in the sixteenth and seventeenth centuries, printing occurred only in exceptional cases: the regulations appear to have circulated mainly by word of mouth. ${ }^{55}$

s1 See Eichhorn, Strukturwandel, p. 300; Scholler, Münzwesen, p.49; RB 5, f. 241v and 249r (1492).

52 Matthias, Has, p. 196. On usage and the rates of exchange of invalid coins, see in detail Groebner, Ökonomie.

${ }_{53}$ The rates of exchange for foreign money prescribed in the city Münzmandaten of 1498 and 1500 applied only to sums of up to $120 \mathrm{~d}$. Where higher sums were concerned the rate could be negotiated freely with the changer. See Scholler, Münzwesen, p. 49.

${ }^{54}$ Staatsarchiv Nürnberg, Rep. 54a, I 111. See also Dirlmeier, Untersuchungen, p. 222.

55 Sachs, 'Metzgergewerbe', p. 22. On craft policy in the Imperial Towns see also H. Lenze, 'Nürnberger Gewerbefassung im Mittelalter,' Jahrbuch für fränkische Landesforschung 24 (1964), 207-82. 
Our picture of economic practice is therefore inevitably distorted by two important facts: on the one hand, we have more access to the text of these normative regulations, such as the craft regulations of the butchers, than the master butchers of the fifteenth century had themselves; about their practical application and interpretation, on the other hand, we-unlike the butchersknow only what we can learn from the fragmentary and sometimes contradictory evidence of the punishment registers and Ratsverlässen. The protocols of the meetings of the Nuremberg council mention sanctions for exceeding the maximum prices much less frequently than their repeated appearances in the punishment registers would suggest was necessary. In 1481 the council decided to sentence the butcher Hans Schaller to four weeks imprisonment in a barred chamber because he had not only exceeded the recommended prices but had also used 'scheltwort' (invectives) against municipal officials. In the previous year another butcher had been banished from the town for two years for calling the sworn masters and the leaders of the council perjurors and attacking them with 'vil unczymlich wortten und flüchen'. ${ }^{56}$ In both cases it was apparently the 'scheltwort' and abuse of its officials, rather than the violations of the price and craft regulations, which were punished so harshly by the council. By contrast, the frequent fines for false weights and exceeding the maximum prices were not so much punishments in our sense of the term as scales of charges. Their main aim did not appear to be the remedying of an undesirable situation, but the provision of a financial yield for the municipal officials.

Every year at Fasnacht, the bailiff, the senior official involved in supervising the crafts, invited the sworn master butchers for refreshments with wine and doughnuts. In his annual account for 1502 this reads: 'Item an der Fasnacht so haben die geschworn meister der fleischhacker nach alter gewohnheit die krapfen geholt haben sie mich kost wie hernach schriben stett 11 ib 20d' (350 d). On Invocation Sunday, the first in Lent, he had hosted a dinner for the sworn master butchers; in 1502 he spent a total of $1,125 d$ on soup, roast and jellied fish, boiled carp, wine, fruit, almonds, and thirty measures of wine (some 32 litres).$^{57}$ What sort of meal was this? The city officials entrusted with the supervision of the foodstuffs trade received only small quarterly salaria as their fixed pay from the city. Otherwise their income consisted of the fines and charges they levied, a part of which they were entitled to keep. Only half the amount taken in fines by the bailiff, for example, went to the city treasury; the other half he kept as his pay, thus receiving a considerable part of his income from the fines imposed on the foodstuffs trade. On the same Invocation Sunday in 1502 when he entertained the butchers with wine, soup, and fish, he had taken no less than $1,100 \mathrm{~d}$ in fines because of the rug of the butchers-

56 RV 136, f. 7v; RB 3, f. 40r.

57 Staatsarchiv Nürnberg, Rep. 54a, I 766, f. 9v. 
sending half to the city treasury and keeping the rest himself. ${ }^{58}$ According to the bailiff's account for $1507-8$, the cost of entertaining the sworn master butchers had risen to $1,485 d$.

There were also similarly expensive gifts of food to the sworn master bakers, half of whose fines the bailiff also pocketed. He was their host on the Monday after Reminiscere (the second Sunday in Lent), when he spent $750 \mathrm{~d}$ on almond soup, pike, carp, roast fish, fifteen measures of wine, and gingerbread.$^{59}$ The bailiff, of course, did not pay for all this food himself: it was provided at the expense of the city. Otherwise it would not have appeared in his accounts, which detailed the city's finances and not his own income and expenditure (although this would have been at least as interesting). This was not a case of 'corruption', then, but related to mutual ties which such functions served to make visible. The Nuremberg regulation of bread and meat prices, and the treatment of those who exceeded them, is best described as a system of charges imposed by the city; the regular symbolic repayments made to the masters by the officials who imposed the charges was part of the system. In fact, the expression 'repayment' is probably not quite accurate. These meals, at which mutual ties were recognized, should be seen not as repayment or compensation but as a form of social hinge. Their role was to bind together the payers and the recipients of the charges and to confirm and strengthen their relationship. It was, moreover, a business relationship at the expense of the municipal consumer.

\section{IV}

Our description of the market in foodstuffs and the reality of prices in a late medieval city has taken in the fluctuations in grain prices, bread weights, cheating, punishment practices, and scales of charges. In other words, it has taken us from the economic context to a consideration of the laws and norms which supposedly regulated the market in foodstuffs. At this point it is necessary to make some observations about the way in which historians deal with these norms and their violation. In view of the ever-present nature and sheer extent of deception and cheating, it is unhelpful to refer simply to deviance or dysfunctionality in these segments of the municipal economy. Such terms are, at the very least, problematic when used to describe preindustrial societies about whose 'functioning' we know so little. In a recent article on the traditional Indian bazaar, Frank Fanselow has revealed that the watering down and adulteration of goods-especially of basic foodstuffs which are bought in small quantities - is part of a specific internal economy. Between the individual sellers within the bazaar there is no sales promotion and very little actual competition. There is extensive uniformity of prices, with the dry

${ }^{5 k}$ Ibid., f. 10r; on the charges see f. $8 \mathrm{v}$. The amount taken by the bailiff here was equivalent to 55 days' wages for a farm labourer in the pay of the Heilig-Geist-Spital or 25 days' wages for a worker in the city.

${ }_{59}$ Ibid. I 955, ff. $9 \mathrm{v}$ and $10 \mathrm{r}$. 
measure of rice costing the same amount throughout the bazaar, but no 'brand loyalty'. This means that the seller makes his profits by manipulating the goods (diluting them with inferior and cheaper substances) and manipulating the weights and measures used in making sales. The system of the bazaar economy consists of goods of different quality being offered at the same price - which the customer must recognize-and in the prevention of lasting ties or loyalty between buyer and seller. For that reason sales between traders, moving goods among themselves, also play an important role. Fanselow deliberately avoids using the word 'cheating' in his analysis because, as he says, both customers and traders are well aware of how the system works and how profits are made. ${ }^{60}$ Of course we cannot say that twentieth-century Asian bazaars function in the same way as fifteenth-century markets in Nuremberg. However, a glance 'over the borders' does serve to reveal the extent to which 'cheating', or the manipulation of goods and weights, can be a generally recognized element in business practice and an integral (if not explicitly accepted) part of an economic system.

Price ranges and comparisons between grain price and money remain an indispensable instrument in any attempt to investigate the purchasing power of wages and the living conditions of late medieval town-dwellers. When we use these instruments, however, we must be aware that the data which underpin them have been obtained by the historian, selected as 'relevant' from the complex realities of conditions in the market, and then given a statistical gloss. Such selection can indeed be representative and highly useful but, as I have attempted to demonstrate, it must not be confused with the actual conditions of exchange obtaining in the foodstuffs market or with the social realities facing the lower classes in the late Middle Ages. Extreme shortterm fluctuations in foodstuffs' prices and widespread cheating, like the frequent references to additional earnings for artisans and day-labourers and forbidden wage supplements in the form of food, cannot be dismissed as mere 'margins of uncertainty' or factors tending to disturb wage and price calculations. They are no less 'relevant' simply because they are not precisely quantifiable and stand in the way of the historian's desire for reliable (numerical) data. If the researcher fails to consider them or, worse, attempts to give them a retrospective statistical gloss in order to 'get them in order', he or she loses sight of a whole series of important factors which helped to shape life in the late medieval towns. It therefore seems necessary to supplement the customary approach of economic history. An attempt should be made not only to deal with the quantifiable 'regular' features of food prices and wage labour, but also to investigate the 'troublesome' and 'irregular' factors which affected prices and wages.

6n F. Fanselow, 'The Bazaar Economy: Or how bizarre is the bazaar really?', Man 25 (June 1990), 250-65. 
In such a detailed analysis in Nuremberg at the end of the fifteenth century, for example, money no longer appears simply as money, but begins to split into different sorts carrying different social connotations and elastic rates of exchange. Alongside money in coin there were other economic media. In late medieval societies marked by recurrent crises of devaluation and money shortage, these Warengelder or Sachgelder, about whose ways of functioning we still know very little, seemed to take over at least some of the functions of money. The arithmetical unit of 'money' was in fact a many-layered and fractured and turbulent social reality. The food-purchasing power of these kinds of money - in our case the weight and quality of bread which could be obtained for one Pfennig between 1470 and 1510-was also subject to enormous fluctuations. A flexible and accommodating adjustment to those urban norms which regulated weight, maximum prices, and market controls also reflected these constant movements, this oscillation of prices and value relations.

This adjustment and the flexible application of norms must be taken seriously if the researcher hopes to do more than simply report 'performance deficits' and the existence of the great 'gulf' between the text of the laws and the sanctions imposed in practice. The criteria normally employed to describe the problem ('weaknesses of early modern statehood', 'dysfunctionality', 'corruption') seem more likely to obscure the phenomena encountered in the sources than to contribute to their description and analysis. The gulf between the norms in the foodstuffs market and actual practice was not an empty space of the kind which appears in the descriptions of historians (especially between different kinds of text, rather than simple 'types of source'). In reality the space is far from empty: it was the sphere marked out by potential sellers on the market and their controllers, and exploited according to their own social and economic logic: to extend their own room for manoeuvre, for conflicts with rivals or institutions on the one hand, for co-operation and the division of labour on the other; to minimize their own risks and expenditures; and, of course, to maximize their own income and prospects of profit.

I hope it has become clear that we are dealing here with economic history in the literal sense-with the analysis of economic practice. This shows us that it can be a mistake to rely on the selection of 'relevant data' with which to project ourselves back 500 years in order to investigate specific areas (in this case the retail trade in foodstuffs), and thus to describe the everyday economic life of late medieval town-dwellers. Research into these economic forms must go beyond the simple description of the norms, which reveal the authorities' claims to make regulations rather than the extent of regulation and discipline actually achieved. Equally, it must also go beyond the infringement of these norms, which are always presented in the city sources as a series of individual cases and as a matter of personal misconduct. Instead, the aim must be to reconstruct the underlying social logic-the egotistic, provisional, day-to-day adjustment of value relations between money and money, and money and 
goods, which appears as the result of mutual trials of strength, negotiations, and business relationships. These relations are subject to rapid changes. For that reason, such manipulations and tricks can be described as 'swings'. By that I do not mean the up-and-down movement of prices, but the manifold techniques encapsulated in the colloquialism 'we'll swing it somehow'-taking people for a ride, making choices, using the system to best effect. It was these socially embedded and competing practices which determined both social and economic conflicts and the conditions of survival in the towns of the late Middle Ages. It is important to reconstruct them if historians wish to avoid the approach of the fifteenth-century authorities themselves, whose laws and regulations were a written attempt to regulate and fix municipal reality 'as it was supposed to be'.

Translated by Louise Willmot 